\title{
Modeling For High Efficiency GaN/InGaN Solar Cell
}

\author{
Manoj Thosar ${ }^{1}$, Manish Mathew ${ }^{2}$ \\ ${ }^{1}$ (Department of Applied Physics, Shri G. S. Institute of Technology \& Science, Indore-452003, India) \\ ${ }_{2}^{2}$ (Optoelectronics Devices Group, Central Electronics Engineering Research Institute, Pilani, Rajasthan \\ 333031, India)
}

\begin{abstract}
GaN/InGaN heterostructure contains a unique property of piezoelectric polarization charges at the interface due to different thermal expansion coefficients. In this paper, we report a simple mathematical model for Ga-face GaN/InGaN heterostructure solar cell. The results obtained from the given model indicates that the piezoelectric polarization charges at the interface of Ga-face GaN/InGaN heterostructure improves the efficiency of a single GaN/InGaN heterostructure photovoltaic solar cell in comparison to the non-polar solar cells by $45 \%$ for AM 1.5. This structure can also provide a fundamental solar cell unit for developing very high efficiency MQW solar cell and a MJ solar cell using Ga-face GaN/InGaN structure.
\end{abstract}

Keywords: GaN/InGaN hetero-structure, Multi-Quantum-Well, Multi-Junction solar cell, Piezoelectric polarization

\section{Introduction}

The III-nitrides offer a great potential to develop high efficiency solar cells due to their wide band gap ranging from $0.65 \mathrm{eV}(\mathrm{InN})$ to $6.2 \mathrm{eV}$ (AlN) [1] and superior photovoltaic characteristics (direct band gap in the entire alloy range, high carrier mobility, drift velocity, radiation resistance and high optical absorption of $10 \%$ cm near the band edge ). A unique property of III-nitrides is the strong polarization, which is due to their non-centrosymmetry structure in nature. These polarizations (spontaneous and piezoelectric) influence their optical and electrical properties of the system and play a significant role in designing of the high efficiency solar cells. This polarization induces an electrical field of the order $\sim 1-2 \mathrm{MV} / \mathrm{cm}$ [2]. The effect of polarization may be used to reduce ohmic contact resistance, to enhance carrier collection and band bending. In this paper, we investigate theoretically the effect of polarization for $\mathrm{Ga}$ - face $\mathrm{GaN} / \mathrm{InGaN}$ heterostructure solar cell grown on sapphire substrate. In Ga-face $\mathrm{GaN} / \mathrm{InGaN}$ heterostructure both spontaneous and piezoelectric polarizations are oriented in opposite directions. These polarization charges may be utilize at interface of the heterostructure to increase the short circuit current of the solar cell, which ultimately improve the performance of solar cell in terms of efficiency.

\section{Model}

In our structure, we have taken a $200 \mathrm{~nm}$ thick $\mathrm{p}-\mathrm{GaN}$ layer above $\mathrm{n}-\mathrm{InGaN}$ of $500 \mathrm{~nm}$ thickness as shown in fig 1. The above structures are on Sapphire substrate. We assume that light enters from p-GaN.

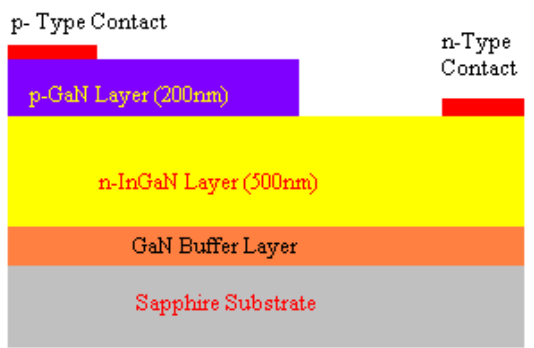

Fig.1. Schematic structure for $\mathrm{p}-\mathrm{GaN} / \mathrm{n}-\mathrm{InGaN}$ solar cell

The effect of polarization in semiconductor materials is expressed by

$$
\mathrm{D}=\varepsilon_{0} \varepsilon_{\mathrm{r}} \mathrm{E}+\mathrm{P}
$$

In equation (1), $\mathrm{D}$ is the displacement vector in dielectric, $\mathrm{E}$ is the electric field $(\mathrm{V} / \mathrm{m}), \mathrm{P}$ is the net polarization in the solar cell structure $\left(\mathrm{C} / \mathrm{m}^{2}\right), \varepsilon_{0}$ is the vacuum permittivity and $\varepsilon_{\mathrm{r}}$ is relative permittivity of the GaN material.

The spontaneous polarization of InGaN layer in terms of Indium composition $\left(\mathrm{x}_{1}\right)$ is [3] 
$\mathrm{P}_{\mathrm{sp}}^{\mathrm{InGaN}}=-0.003 \times \mathrm{x}_{1}-0.029$

The piezoelectric polarization InGaN layer in terms of Indium composition $\left(\mathrm{x}_{1}\right)$ is [4]

$\mathrm{P}_{\mathrm{pz}}^{\mathrm{InGaN}}=0.176 \times \mathrm{x}_{1}$

The spontaneous polarization of GaN layer will be fixed and its value is [5]

$\mathrm{P}_{\mathrm{sp}}^{\mathrm{GaN}}=-0.034 \mathrm{C} / \mathrm{m}^{2}$

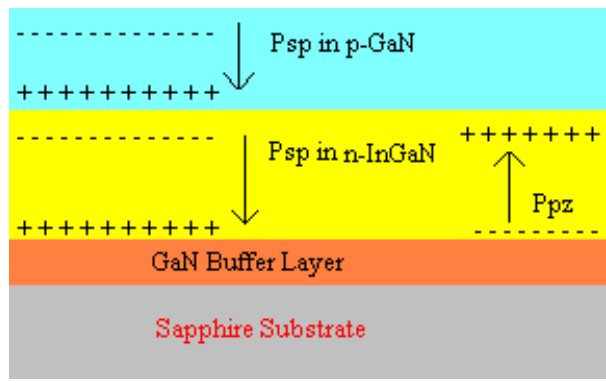

Fig.2. Orientation of polarizations in Ga-face p-GaN/n-InGaN heterostructure.

The orientation of all these polarizations in Ga-face p-GaN/n-InGaN heterostructure is shown in fig. 2 and according to it the net polarization in $\mathrm{n}-\mathrm{InGaN}$ layer at the interface is $\mathrm{P}=\mathrm{P}_{\mathrm{pz}}^{\mathrm{InGaN}}+\left(\mathrm{P}_{\mathrm{sp}}^{\mathrm{InGaN}}-\mathrm{P}_{\mathrm{sp}}^{\mathrm{GaN}}\right)$

The net polarization charges at the interface of $\mathrm{p}-\mathrm{GaN} / \mathrm{n}-\mathrm{InGaN}$ heterostructure will be [1]

$\sigma_{\mathrm{s}}=\mathrm{P} / \mathrm{q}$

Where, $\mathrm{q}$ is the electronic charge.

In this heterostructure solar cell, we assume that light enters the $\mathrm{p}$-n diode from the wide band gap side as shown in fig. 3 .

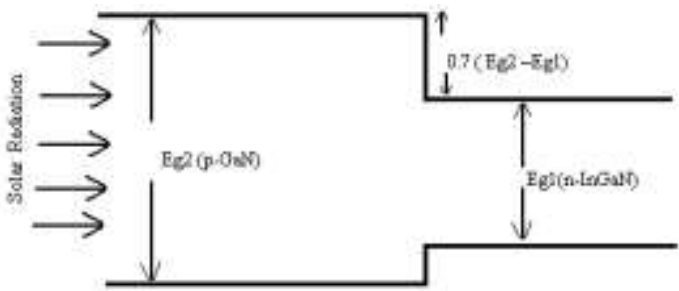

Fig. 3. Energy band diagram of $\mathrm{p}-\mathrm{GaN} / \mathrm{n}-\mathrm{InGaN}$ heterostructure

Photons with energies greater than $\mathrm{E}_{\mathrm{g} 2}$ are absorbed by the top p-type layer and photons with energies between $\mathrm{E}_{\mathrm{g} 2}$ and $\mathrm{E}_{\mathrm{g} 1}$ are absorbed by the smaller band gap n-type layer. The resultant short circuit current and open circuit voltage for this structure is limited by the smaller band gap region. The piezoelectric polarization charges will also contribute into the photo-generated current. Thus, photocurrent (short circuit current) in this heterostructure solar cell is represented by

$\mathrm{I}_{\mathrm{SC}}=\mathrm{q} \times[1-\alpha(\mathrm{x})] \times[1-\mathrm{R}] \times \int_{\lambda E g 2}^{\lambda E g 1} N(\lambda)(\operatorname{dnph} / \mathrm{d} \lambda+\sigma \mathrm{s}) \mathrm{d} \lambda$

In the above equation (7), $\alpha(\mathrm{x})$ is the absorption of optical power with respect to distance. Studies indicate that in $\mathrm{GaN}$ about $99 \%$ optical power is absorbed at $500 \mathrm{~nm}$ distance [6]. $\mathrm{R}$ is the reflectance at air-GaN interface (about 18\%) [7, 8], $\mathrm{N}(\lambda)$ is the collection efficiency representing the number of electron-hole pairs generated from the absorbed photons. $\mathrm{dn}_{\mathrm{ph}} / \mathrm{d} \lambda$ is the number of incident photons per $\mathrm{cm}^{2}$ per second at a particular wavelength of the solar spectrum and calculated using $2 \pi v \mathrm{c}^{2} /$ [exp (hv/KT)-1]. Integration limits $\lambda \mathrm{Eg} 1$ is the wavelength corresponding to the band gap of $n-\operatorname{InGaN}$ layer and $\lambda \mathrm{Eg} 2$ is the wavelength corresponding to the band gap of $\mathrm{p}-\mathrm{GaN}$ layer. $\sigma_{\mathrm{s}}$ is the piezoelectric charges at the interface of $\mathrm{p}-\mathrm{GaN} / \mathrm{n}$-InGaN heterostructure. 
The open circuit voltage for $\mathrm{p}-\mathrm{GaN} / \mathrm{n}-\mathrm{InGaN}$ hetero-structure solar cell is $\mathrm{V}_{\mathrm{OC}}=(\mathrm{KT} / \mathrm{q}) \times \ln \left[\left(\mathrm{I}_{\mathrm{sc}} / \mathrm{I}_{0}\right)+1\right]$

Where, $\mathrm{K}$ is the Boltzmann constant, $\mathrm{T}$ is the operating temperature, $\mathrm{I}_{\mathrm{sc}}$ is the photo-generated current and $I_{0}$ is the reverse saturation current. The saturation current in $\mathrm{p}-\mathrm{GaN} / \mathrm{n}$-InGaN hetero-structure is

$\mathrm{I}_{0}=\mathrm{qA} \times\left[\left(\mathrm{D}_{\mathrm{n}} \times \mathrm{n}_{\mathrm{i}}{ }^{\mathrm{P}-\mathrm{GaN}}\right) /\left(\mathrm{L}_{\mathrm{n}} \times \mathrm{N}_{\mathrm{A}}^{\mathrm{P}-\mathrm{GaN}}\right)+\left(\mathrm{D}_{\mathrm{P}} \times \mathrm{n}_{\mathrm{i}}{ }^{\mathrm{n}-\mathrm{InGaN}}\right) /\left(\mathrm{L}_{\mathrm{p}} \times \mathrm{N}_{\mathrm{D}}{ }^{\mathrm{n}-\mathrm{InGaN}}\right)\right]$

Where, $A$ is the front cross section area of the solar cell. $D_{n}$ and $D_{P}$ are the diffusion coefficient for electrons in $\mathrm{p}-\mathrm{GaN}$ and for the holes in $\mathrm{n}-\mathrm{InGaN}$. These diffusion coefficients are calculated by $\mathrm{D}_{\mathrm{n}}=\frac{K T}{q} \mu_{\mathrm{n}}$ and $\mathrm{D}_{\mathrm{P}}=\frac{K T}{\mathrm{q}} \mu_{\mathrm{p}}$.

Where, $\mu_{n}$ and $\mu_{p}$ are the mobility of electron and hole, $L_{n}$ and $L_{p}$ are the minority carrier electron and hole diffusion lengths calculated by $L_{n}=\left[D_{n} \tau_{n}\right]^{1 / 2}$ and $L_{P}=\left[D_{P} \tau_{P}\right]^{1 / 2}$. Where $\tau_{n}$ and $\tau_{P}$ are the average recombination time for electrons and holes, $n_{i}{ }^{P-G a N}$ and $n_{i}{ }^{n-I n G a N}$ are the intrinsic concentration in $p-G a N$ and $n-$ InGaN, $\mathrm{N}_{\mathrm{A}}{ }^{\mathrm{P}-\mathrm{GaN}}$ and $\mathrm{N}_{\mathrm{D}}{ }^{\mathrm{n}-\mathrm{InGaN}}$ are the external doping in $\mathrm{p}-\mathrm{GaN}$ and $\mathrm{n}$-InGaN. The fill factor is

F.F. $=\mathrm{V}_{\mathrm{m}} \mathrm{I}_{\mathrm{m}} / \mathrm{V}_{\mathrm{OC}} \mathrm{I}_{\mathrm{SC}}$

Where, $V_{m}$ is the maximum voltage across the load resistance and $I_{m}$ is the maximum current in the load Resistance. For GaN based good performance solar cell its value is greater than 70\% [10]. The external quantum efficiency of $\mathrm{p}-\mathrm{GaN} / \mathrm{n}-\mathrm{InGaN}$ heterostructure solar cell

$\eta_{\mathrm{e}}=\mathrm{V}_{\mathrm{m}} \mathrm{I}_{\mathrm{m}} / \mathrm{P}_{\text {in }}$

Where, $\mathrm{P}_{\text {in }}$ is total incident solar power absorb by solar cell.

\section{Results And Discussion}

For above model we calculate the values of short circuit current $\left(\mathrm{I}_{\mathrm{SC}}\right)$, open circuit voltage $\left(\mathrm{V}_{\mathrm{OC}}\right)$ and external quantum efficiency $\left(\eta_{\mathrm{e}}\right)$ using parameter values listed in table-1.

\begin{tabular}{|l|l|l|}
\hline S.No. & \multicolumn{1}{|c|}{ Parameters } & \multicolumn{1}{c|}{ Parameter Value } \\
\hline 1 & Indium composition $(\mathrm{x})$ & 0.2 \\
\hline 2 & External doping in p-GaN & $5.1 \times 0^{17} \mathrm{~cm}^{-3}$ \\
\hline 3 & External doping in n-InGaN & $5 \times 10^{18} \mathrm{~cm}^{-3}$ \\
\hline 4 & Intrinsic concentration in p-GaN & $2.35 \times 10^{-10} \mathrm{~cm}^{-3}$ \\
\hline 5 & Intrinsic concentration in n-InGaN & $7.21 \times 10^{-4} \mathrm{~cm}^{-3}$ \\
\hline 6 & Recombination time for electron $[9]$ & $2 \times 10^{-9} \mathrm{Sec}$ \\
\hline 7 & Recombination time for hole $[9]$ & $2 \times 10^{-9} \mathrm{Sec}$ \\
\hline 8 & Reflectance at air-GaN interface $[7,8]$ & 0.18 \\
\hline 9 & Collection efficiency & 0.7 \\
\hline 10 & Temperature equivalent voltage & $0.026($ at $300 \mathrm{~K})$ \\
\hline 11 & Mobility of electron $[9]$ & $440 \mathrm{~cm}^{2} / \mathrm{V} . \mathrm{sec}$ \\
\hline 12 & Mobility of hole [9] & $10 \mathrm{~cm}^{2} / \mathrm{V} . \mathrm{sec}$ \\
\hline
\end{tabular}

Table-1

Table- 2 shows the calculated values of short circuit current $\left(\mathrm{I}_{\mathrm{SC}}\right)$, open circuit voltage $\left(\mathrm{V}_{\mathrm{OC}}\right)$ for both without polarization effect and with polarization effect using the above model.

\begin{tabular}{|l|c|c|}
\hline \multicolumn{1}{|c|}{ Type } & $\mathrm{I}_{\mathrm{SC}}\left(\mathrm{mA} / \mathrm{cm}^{2}\right)$ & $\mathrm{V}_{\mathrm{OC}}($ Volt $)$ \\
\hline Without polarization effect & 1.88 & 1.96 \\
\hline With polarization effect & 3.40 & 1.98 \\
\hline
\end{tabular}

Table-2 
Fig. 4 shows the curve between the short circuit current and open circuit voltage with polarization and without polarization effect.

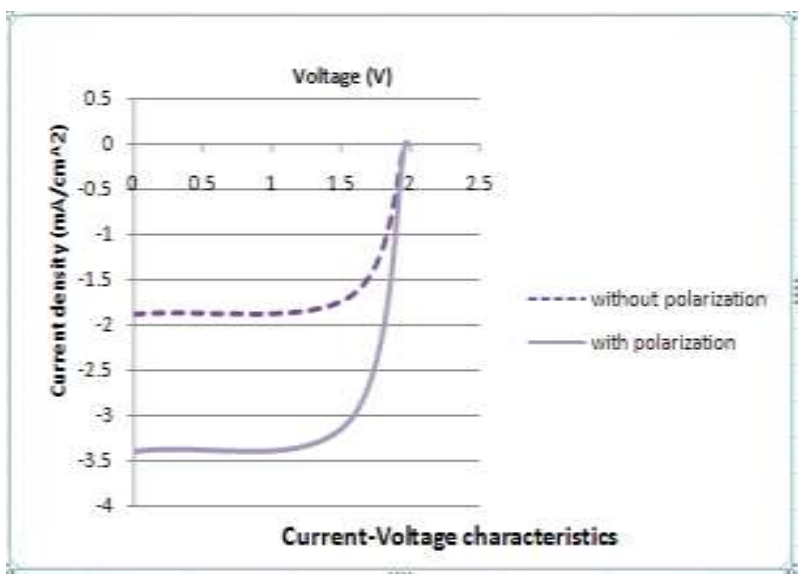

Fig. 4. Current-voltage characteristics

The values of $\mathrm{I}_{\mathrm{SC}}$ and $\mathrm{V}_{\mathrm{OC}}$ in table 2 indicate that the open circuit voltage and short circuit current of the solar cell increases due to piezoelectric polarization induced charges at the interface of $\mathrm{p}$-GaN/n-InGaN heterostructure. The value of short circuit current increases from $1.88 \mathrm{~mA} / \mathrm{cm}^{2}$ to $3.40 \mathrm{~mA} / \mathrm{cm}^{2}$ and open circuit voltage increases from 1.96 Volt to 1.98 Volt. These results clearly indicate that the increase in efficiency of Ga-face p-GaN/n-InGaN heterostructure solar cell is mostly due to increase in short circuit current (from 1.88 $\mathrm{mA} / \mathrm{cm}^{2}$ to $3.40 \mathrm{~mA} / \mathrm{cm}^{2}$ ) of the solar cell.

\section{Conclusions}

From above discussion we conclude that by using Ga-face p-GaN/n-InGaN heterostructure for the solar cell design the value of short circuit current increases by $44 \%$ and the open circuit voltage increases by $1 \%$. Thus net improvement in external quantum efficiency of the solar cell is about 45\% for AM 1.5. This is a large improvement in the performance of a single heterojunction photovoltaic solar cell, thus encourages us to use the Ga-face p-GaN/n-InGaN heterostructure solar cell structure in multi-quantum-well solar cell and multi-junction solar cell to design very high efficiency photovoltaic solar cell.

\section{References}

[1] MMehta,OJan,CHonsbergBJampana,IFerguson,ADoolittle,Modifying PC1D to model spontaneous and piezoelectric polarization in III-V nitride solar cell, 22nd European Photovoltaic Solar Energy Conference, 3-7 September, Milan Italy (2007) 409-413.

[2] O.Jani,C.Honsberg,Y.Huang,J.O.Song,I.Ferguson,G.Namkoong,E.Trybus,A.Doolittle,S.Kurtz,Design,Growt h,Fabrication and Characterization of High-BandGap InGaN/GaN Solar Cells, Proc. of the IEEE 4th World Conference on Photovoltaic Energy Conversion, Waikoloa, Hawaii, May 7-12, 2006.

[3] RudigerQuay, GalliumNitrideElectronics, SpringerSeriesInMaterials science 96, 2008, 30

[4] H. Morkoc, Nitride Semi-conductor and Devices, Springer Series in Materials Science 32, $1999,73$.

[5] O. Ambacher, J. Majewski, C. Miskys, A. Link, M. Hermann, M. Eickhoff, M. Stutzmann, F. Bernerdini, V. Fiorentini, V. Tilak, B. Schaff, L. F. Eastman, Pyroelectric properties of Al(In)GaN/GaN hetero and quantum well structures, J. Phys.: Condens. Matter, vol. 14 (2002) 3399-3434

[6] Omkar Jani, Ian Ferguson, Christiana Honsberg, Sarah Kurtz, Design and characterization of GaN/InGaN solar cells, Applied Physics Letters 91 (2007) 132117-1-3

[7] E.A.Berkman,N.A.El-Masry,A.Emara,ands.M.Bedair,Nearlylattice-matched n, i, and p layers for InGaN p-i-n photodiodes in the 365-500 nm spectral range, Appl. Phys.Lett. 92 (2008) 101118-1-3

[8] M.J.Bergmann,U.Ozgur,J.Casey,H.O.Everitt and J.F. Muth, Ordinary and extraordinary refractive indices for AlxGa1-xN epitaxial layers, Appl. Phys. Lett. 75 (1999) 67-69.

[9] Omkar Jani, Christiana Honsberg, Ali Asghar, David Nicol, Ian Ferguson, Alan Dwliffle, Sarah Kurtz Characterization and analysis of InGaN photovoltaic devices, Photovoltaic 31st IEEE Specialists Conference, Lake Buena, Vista, FL Jan. 3-5 (2005)

[10] Jenny Nelson “The Physics of Solar Cells.” Imperial College Press.(2003).ISBN978-1-86094-340-9. http://www.solarfreaks.com/download/file.php?id=281 